\title{
Detection of Listeria spp. in food handling areas of retail food stores in the state of Pernambuco, Brazil
}

\author{
Pesquisa de Listeria spp. em áreas de manipulação de alimentos de estabelecimentos \\ varejistas no estado de Pernambuco, Brasil
}

\section{Mariana Gomes Ferreira Machado de Siqueira1', Jean Carlos Ramos da Silva1, Érica Chaves Lúcio1, Pomy de Cássia Peixoto Kim¹, Leandro Fragoso Lins ${ }^{1}$, José Wilton Pinheiro Junior ${ }^{1 *}$, Rinaldo Aparecido Mota ${ }^{1}$, Andréa Paiva Botelho Lapenda de Moura ${ }^{1}$}

\begin{abstract}
${ }^{1}$ Universidade Federal Rural de Pernambuco - (UFRPE), Departamento de Medicina Veterinária (DMV), Laboratory of Infectious Contagious Diseases, Recife/PE - Brazil
\end{abstract}

\section{*Corresponding Author}

José Wilton Pinheiro Junior, Universidade Federal Rural de Pernambuco (UFRPE), Departamento de Medicina Veterinária (DMV), Laboratory of Infectious Contagious Diseases, Rua Dom Manoel de Medeiros, s/n, Dois Irmãos, CEP: 52171-900, Recife/PE, Brazil, e-mail: wiltonjrufrpe@gmail.com

Cite as: Detection of Listeria spp. in food handling areas of retail food stores in the state of Pernambuco, Brazil. Braz. J. Food Technol., v. 20, e2016138, 2017.

\section{Abstract}

The identification of Listeria spp. in food handling areas is of great concern to health surveillance agencies, and their control is often hampered by the ability of the bacteria to grow and maintain themselves even under adverse conditions. The present study aimed to isolate and identify Listeria spp. in the food handling areas of 10 retail food stores in the state of Pernambuco, Brazil. Eighty-six swab samples were collected from equipment, utensils and surfaces used for processing

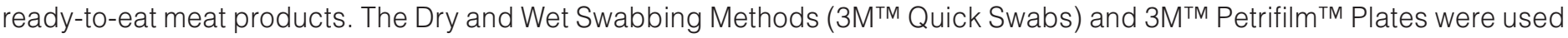
to identify Listeria spp. Contamination by Listeria monocytogenes was confirmed by the Real-time Polymerase Chain Reaction (qPCR). The hygienic and sanitary conditions of the food handling areas of each store were also assessed. Listeria spp. was isolated in eight stores (80\%). Of the 86 swab samples analyzed, 27 (31.2\%) [confidence interval $21.81 \%$ to $42.30 \%$ ] were positive for Listeria spp. and only one (3.7\%) was confirmed as Listeria monocytogenes. The main contamination sites were the floor $(50.0 \%)$, the plastic cutting board $(42.9 \%)$ and the knife $(40.0 \%)$. None of the hygienic and sanitary conditions assessed in the present study were associated with contamination by Listeria spp. $(p=0.700)$. It was concluded that Listeria spp. was widely distributed in the retail food stores studied, being a possible risk factor for public health.

Keywords: Good manufacturing practices; Listeria monocytogenes; Public health; Supermarket.

\section{Resumo}

A identificação de Listeria spp. em áreas de manipulação de alimentos é de grande preocupação para as agências de vigilância da saúde. O seu controle, muitas vezes, é prejudicado pela capacidade da bactéria em crescer e se manter no ambiente mesmo sob condições adversas. Objetivou-se, com este estudo, isolar e identificar Listeria spp. em áreas de manipulação de estabelecimentos varejistas de alimentos no Estado de Pernambuco, Brasil. Foram colhidas 86 amostras de swabs, procedentes de equipamentos, utensílios e instalações utilizados para processamento de embutidos cárneos, distribuídas em dez estabelecimentos varejistas. Para identificação de Listeria spp., utilizaram-se os métodos rápidos

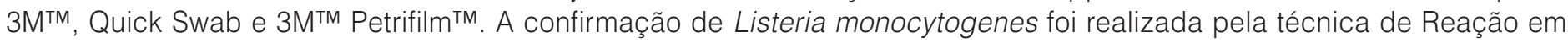
Cadeia da Polimerase em Tempo Real (qPCR). Nos estabelecimentos, foi realizada uma lista de verificação para avaliar as condições higiênico-sanitárias dos pontos de coletas. Das 86 amostras analisadas, 27 (31,2\%) [intervalo de confiança $21,81 \%$ a $42,30 \%$ ] foram positivas para Listeria spp. e, destas, uma (3,7\%) para Listeria monocytogenes. Os pontos de maior contaminação foram o piso (50,0\%), a placa de polietileno (42,9\%) e a faca $(40,0 \%)$. Dos dez estabelecimentos analisados, observou-se que oito $(80,0 \%)$ tiveram ao menos uma amostra positiva para Listeria spp. Ao analisar a associação entre as condições higiênico-sanitárias dos pontos de coletas e o exame microbiológico, foi constatado não haver diferença 
significativa $(p=0,700)$. Diante dos resultados obtidos, conclui-se que a Listeria spp. está amplamente distribuída nos ambientes estudados, o que pode favorecer a contaminação dos alimentos e, consequentemente, oferecer riscos à saúde pública. Desta forma, recomenda-se que parâmetros microbiológicos devem ser estabelecidos pelos órgãos reguladores de saúde para alimentos cárneos e seus embutidos, com o intuito de oferecer um alimento seguro para os consumidores.

Palavras-chave: Boas práticas de fabricação; Listeria monocytogenes; Saúde pública; Supermercados.

\section{- 1 Introduction}

Listeria monocytogenes is a microorganism that requires attention in food handling areas due to some peculiarities that facilitate its occurrence even under adverse conditions, and the application of sanitizers is recommended by sanitary regulations (BRASIL, 2001, 2009). The peculiarities include biotransference and the formation of biofilms, both in the food and on other non-nutritive surfaces which promote adhesion and protection to the microorganism. This species requires a minimum of nutrients for growth; it is capable of multiplying under refrigeration temperatures, at low $\mathrm{pH}$ values and high salt concentrations (LEONG et al., 2014; TEIXEIRA et al., 2016).

The presence of Listeria spp. in industries and meat processing facilities has been previously reported in Brazil (CASELANI et al., 2013; YAMAGUCHI et al., 2013; MONTEIRO et al., 2014). In Switzerland, Blatter et al. (2010) detected L. monocytogenes in only 3.5\% (70/2028) of the samples collected from handling areas of ready-to-eat food. On the other hand, in Italy, 44.9\% (19/43) of the samples from food processing areas were contaminated by $L$. monocytogenes (PARISI et al., 2013). Epidemiological and microbiological studies have shown that cross-contamination during slicing and bacterial growth during storage are the main contributors to contamination of ready-to-eat foods and the causes of the diseases transmitted by these foods (PÉREZ-RODRÍGUEZ et al., 2010). In addition, the concern of industries and regulatory agencies about contamination by Listeria spp. has increased, especially due to antimicrobial resistant strains, which pose a potential risk to human health (GELBí OVÁ et al., 2016; SU et al., 2016).

The criteria "absence of $L$. monocytogenes" has been adopted by several countries for ready-to-eat foods in general, or just for items specific for risk groups or for those that favor bacterial growth. RDC Resolution number 12 of the Brazilian National Health Surveillance Agency (Agência Nacional de Vigilância Sanitária - ANVISA) (BRASIL, 2001) stipulates the microbiological standards for $L$. monocytogenes in cheese but does not contemplate the presence of Listeria spp. in any other products of animal origin or in industrial food facilities.

The presence of Listeria spp. in food handling areas of products of animal origin is a concern to health surveillance agencies. However, there is no study on the presence of this microorganism in industries and retail food stores in the Northeast of Brazil. Therefore, the aim of the present study was to isolate and identify Listeria spp. in the food handling areas of retail stores in the state of Pernambuco, Brazil.

\section{Materials and methods}

\subsection{Samples}

Eighty-six swab samples were collected from handling areas of ready-to-eat meat products in 10 retail food stores located in the municipalities of Caruaru, Jaboatão dos Guararapes and Recife, state of Pernambuco, Brazil, using convenience non-probabilistic sampling. One swab sample was collected from each of the following sampling sites in each store: the scale, the refrigerated counter, the knife, the slicer, the processing table, the plastic cutting board, the wall, the floor and the floor drain.

The Dry and Wet Swabbing Methods ( $3 \mathrm{M}^{\mathrm{TM}}$ Quick Swabs) (Saint Paul, USA) were used according to the manufacturer's instructions. Stainless steel stylized moulds $\left(10 \mathrm{~cm}^{2}\right)$ were also used as described by Lakicevic et al. (2010). The entire surface of the knife and the floor drain were sampled because they did not fit into the stainless steel stylized mould. The 3M ${ }^{\mathrm{TM}}$ Quick Swabs were stored under refrigeration in an isothermal box with reusable ice packs and sent to the laboratory for analysis.

\subsection{Microbiological analysis for Listeria spp.}

The samples were inoculated onto $3 \mathrm{M}^{\mathrm{TM}}$ Petrifilm ${ }^{\mathrm{TM}}$ Environmental Listeria (EL) Plates (Saint Paul, USA) and incubated at $37{ }^{\circ} \mathrm{C} \pm 1{ }^{\circ} \mathrm{C}$ for 28 to 30 hours, following the manufacturer's instructions. Suspect colonies were then placed in microtubes with phosphate buffered saline solution (PBS) for later molecular identification.

\subsection{Molecular identification of Listeria monocytogenes}

The DNA was extracted using the Mericon DNA Bacteria Plus Kit (Qiagen ${ }^{\circledR}$, Hilden, Germany) following the manufacturer's protocol. Bacterial DNA was detected using a qPCR protocol adapted from Barocci et al. (2008) with the listeriolysin O ( $h l y A)$ gene, the sequence necessary for L. monocytogenes pathogenesis. The primers LL5 (5'- AACCTATCCAGGTGCTC-3') and LL6 (5'-CTGTAAGCCATTTCGTC-3') were applied, and the real-time amplification reactions were carried out in a final volume of $25 \mu \mathrm{l}$ containing $12.5 \mu \mathrm{l}$ of QuantiFast 
SYBR Green PCR Kit (Qiagen ${ }^{\circledR}$, Hilden, Germany), $1.0 \mu \mathrm{l}$ of each primer (LL5 and LL6) (30 pmol), $5.0 \mu \mathrm{l}$ of genomic DNA $(<120 \mathrm{ng} / \mathrm{\mu L})$ and $5.5 \mu \mathrm{l}$ of Nuclease-Free ultrapure water (Amresco ${ }^{\circledR}$, Ohio, USA). The qPCR was carried out in a Rotor-Gene $Q$ thermocycler (Qiagen ${ }^{\circledast}$, Hilden, Germany) and consisted of an initial denaturation at $95^{\circ} \mathrm{C}$ for 5 minutes, followed by 35 cycles of $95^{\circ} \mathrm{C}$ for 1 minute (denaturation) and $60^{\circ} \mathrm{C}$ for 30 seconds (annealing and extension). Optimization of the qPCR was achieved using the QuantiFast SYBRGreen (Qiagen ${ }^{\circledast}$, Hilden, Germany) recommendations with combined annealing and extension temperatures in one step. This particular temperature combination should be used for all primer sets with a $\mathrm{Tm}$ value below $60^{\circ} \mathrm{C}$, such as Tm values of LL5 $\left(50.9^{\circ} \mathrm{C}\right)$ and LL6 $\left(47.7^{\circ} \mathrm{C}\right)$. DNA positive samples for $L$. monocytogenes and Nuclease-Free ultrapure water (Amresco ${ }^{\circledR}$, Ohio, USA) were included as the positive and negative controls, respectively. Data acquisition and analysis of the qPCR were carried out using the Rotor-Gene Q Series Software (Qiagen ${ }^{\circledast}$, Hilden, Germany) Version 1.7.

\subsection{Assessment of the hygienic and sanitary conditions}

At the time of sample collection, a checklist was used to assess the hygienic conditions of the equipment of each store studied, focusing on the handling areas of ready-to-eat processed meat products (BLATTER et al., 2010; PÉREZ-RODRÍGUEZ et al., 2010).

\section{Results}

Listeria spp. was isolated in eight $(80 \%)$ of the 10 retail food stores visited. Of the 86 samples analysed, 27 (31.39\%) were positive for Listeria spp. and only one (3.70\%) was confirmed as Listeria monocytogenes by qPCR.

Listeria spp. was isolated from all the sampling sites evaluated (Table 1). The floor $(50.0 \%)$, the floor drain $(42.9 \%)$, the plastic cutting board $(40.0 \%)$ and the knife $(40.0 \%)$ were the sampling sites with the highest frequency of contamination.

In most of the stores, hand hygiene was inadequately carried out, gloves were improperly used and food-handling utensils were absent, which may increase the risk of contamination by Listeria spp. Inappropriate use of gloves by handlers was observed in all stores - including inadequate glove adjustment, contacting soiled surfaces and not replacing gloves after contamination were practices commonly witnessed. Most of the stores did not have a sink dedicated to hand hygiene. The sinks were often used for other purposes like washing utensils, or did not have an adequate supply of antibacterial soap or paper towels. The hand washing procedure was fixed in an appropriate place in only one store.

\section{Discussion}

This is the first record of the occurrence of Listeria spp. in food handling areas of retail food stores in the state of Pernambuco, Brazil. Similar results have been found in other Brazilian states (SILVA et al., 2010; CESAR et al., 2011; FERRONATTO et al., 2012; YAMAGUCHI et al., 2013), and the different results obtained in the aforementioned studies may have been related to both the sampling sites and the sampling and diagnostic methods used in each study.

The high incidence of Listeria spp. observed in the stores visited in the present study is of concern since cross-contamination may occur between foods, and as a consequence, cause listeriosis outbreaks. The report from the European Food Safety Authority (EFSA) showed an increasing trend for listeriosis in the EU over the period 2008-2014. In 2014 there was a 30\% increase in the number of cases of listeriosis as compared to 2013, and a total of 210 deaths were reported (EFSA; ECDC, 2016). In the United States, a similar scenario was also described by the Centers for Disease Control and Prevention, with 9 outbreaks and 13 deaths due to L. monocytogenes in 2014 (CDC, 2015). In Brazil, listeriosis is underdiagnosed

Table 1. Detection of Listeria spp. in the food handling areas of retail food stores in the State of Pernambuco, Brazil.

\begin{tabular}{lcccc}
\multicolumn{1}{c}{ Sampling points } & N & \multicolumn{2}{c}{ Listeria spp. } \\
\cline { 2 - 4 } Balance & 10 & A.F. & R.F. (\%) & C.I. (95.0\%) \\
Plastic cutting board & 10 & 3 & 30 & {$[6.67-65.24]$} \\
Knife & 10 & 4 & 40 & {$[12.15-73.76]$} \\
Table & 10 & 4 & 40 & {$[12.15-73.76]$} \\
Slicer & 9 & 3 & 30 & {$[69.15-100]$} \\
Refrigerated displays & 10 & 1 & 30 & {$[0.28-48.25]$} \\
Wall & 10 & 3 & 10 & {$[6.67-65.24]$} \\
Floor & 10 & 5 & 50 & {$[0.25-44.50]$} \\
Floor drain & 7 & 3 & 42.9 & {$[18.70-81.29]$} \\
\hline
\end{tabular}

$\mathrm{N}=$ Sample number; A.F.= Absolute frequency; R.F.= Relative frequency; $\mathrm{C} . \mathrm{I} .=$ Confidence interval. 
and underreported, although some researchers have indicated the presence of Listeria (CRUZ et al., 2008; BARANCELLI et al., 2011).

Transmission of Listeria spp. to humans occurs mainly via food such as raw or pasteurized milk, dairy products, raw or processed meat products from various sources and ready-to-eat foods (SEYOUM et al., 2015; SÖDERQVIST et al., 2016; RODRIGUES et al., 2017). It is noteworthy that the meals prepared in the food handling areas of the retail food stores evaluated in the present study did not receive any heat treatment prior to commercialization. This practice may increase the risk of contamination, especially for people at higher risk to develop listeriosis, which includes pregnant women, children, elderly people and immunocompromised clients (LOTFOLLAHI et al., 2017).

Only one sample (3.7\%), which was isolated from a plastic cutting board, was identified as L. monocytogenes. In the state of Goiás, Brazil, Cesar et al. (2011) reported 50\% positivity for L. monocytogenes in six sets of environmental swabs from the sausage industry. In the state of Paraná, Brazil, of 54 samples positive for Listeria, 11.11\% were identified as L. monocytogenes (YAMAGUCHI et al., 2013).

The low incidence of $L$. monocytogenes detected in the present study might be related to competition with other pathogens and/or different species of Listeria that share the same environment. The growth of $L$. monocytogenes can be inhibited by several factors such as stress, the initial number of bacteria in the environment and the presence of other microorganisms.

Listeria spp. was isolated from $80 \%$ of the stores analyzed showing that this bacterium is widely distributed in the retail food stores of the studied area and that control measures must be implemented.

The floor was the sampling site with the highest incidence of Listeria spp. (50\%). This number could have been higher considering the poor hygienic and sanitary conditions observed in the retail food stores. The floors of all stores were inadequately cleaned which may also justify the low incidence of $L$. monocytogenes.

Listeria spp. was found in $42.8 \%(3 / 7)$ of the floor drains sampled. Although the drainage system and the floor are not considered food contamination sources, these locations serve as an indication of Listeria spp. contamination at the sampling sites.

The plastic cutting board was the utensil with the highest incidence of Listeria spp. (40.0\%), and the only site where L. monocytogenes was identified. The plastic cutting board was routinely used to open packages and to slice products; and the cut marks (grooves) allow for the accumulation of organic material, which hinders proper cleaning and enables the formation of a biofilm. Biofilm formation is influenced by several factors such as sample characteristics, physicochemical properties of the bacterial substrates, bacterial growth phase, temperature and the presence of other microorganisms (MAGALHÃES et al., 2017; SILVA et al., 2017)

Despite the low frequency of Listeria spp. on the slicers $(11.11 \%)$, the process of slicing ready-to-eat foods is considered to be a contamination source because the food residues that accumulate in these machines may result in good growth conditions, biofilm formation and product contamination during the operation (KAPETANAKOU et al., 2016). Ready-to-eat foods are potential transmitters of pathogens due to their handling and storage conditions (MUHTEREM-UYAR et al., 2015); however, in Brazil, there are few reports on the occurrence of Listeria spp. in supermarket facilities and equipment.

Cesar et al. (2011) stated that equipment parts that are difficult to sanitize, such as conveyors, grinders, slicers and packaging machines are the main site of contamination by L. monocytogenes even after cleaning.

The presence of Listeria spp. is related to the hygienic and sanitary conditions of the food handling areas, and this bacterium is able to survive and multiply under adverse conditions (FERREIRA et al., 2014). The cleaning and sanitizing processes carried out at the stores did not comply with the requirements of the ANVISA RDC number 216 (BRASIL, 2004), and may therefore have favoured environmental and food contamination. The cleaning and sanitizing schedules were not displayed at the food handling areas of the stores, there was no controlled access to the handling areas, and cutting took place in non-designated areas, without proper cleaning or an air-conditioned environment.

Lakicevic et al. (2010) stated that the detection of Listeria spp. is an indicator of an inadequate hygiene and/or cleaning process in food handling areas. It is important to highlight that the detection of Listeria spp. is a public health concern since it increases the chance of L. monocytogenes contamination; therefore preventive actions must be initiated. According to Barancelli et al. (2011), it is difficult to control L. monocytogenes in food handling areas because it originates in the environment. Thus products and environmental samples should frequently be evaluated to effectively control this pathogen in food handling areas.

Hoelzer et al. (2012) reported that hands and gloves are an important source of cross-contamination and the implementation of better hygienic practices such as an increased frequency of handwashing and the proper use of gloves are necessary to decrease the occurrence of Listeria spp. in food. According to Codex (WHO, 2009), the hygiene practices of food handlers are important to prevent L. monocytogenes contamination, and workers must be provided with appropriate training and supervision to ensure compliance with these practices. Luber et al. (2011) recommended that companies should offer training with up to date approaches and suitable to each scenario, 
and regulatory agencies should emphasize the need for the effective training of food handlers, especially in places where L. monocytogenes growth is viable.

Although no association between the hygiene level of the food handling areas and the microbiological analysis was identified, hygiene measures must be implemented at the stores studied, since places with poor hygiene have a higher frequency of microbial isolation (PÉREZ-RODRíGUEZ et al., 2010).

It is difficult to identify exactly when contamination occurred during the processing and handling procedures. The authors believe that the source of contamination in the stores studied was the footwear of the people circulating in the food handling areas, or the products were already contaminated. According to Gandhi and Chikindas (2007), the contamination of foods can occur during any stage of the manufacturing or processing phase, but post-process contamination of foods has been the major cause of many outbreaks, and the most important sources of recontamination are raw materials added to finished processed food, food contact surfaces and environments, defective packaging and food handling personnel.

The presence of Listeria spp. in the food handling areas supports the need for the existence and maintenance of an environmental monitoring program for this pathogen, especially for working surfaces that are in direct contact with ready-to-eat foods such as processed meat (CESAR et al., 2011). Finally, good handling practices are important prevention tools to ensure the hygienic and sanitary quality of foods, consequently reducing food contamination and foodborne disease outbreaks (BRASIL, 2004; PÉREZ-RODRÍGUEZ et al., 2010).

\section{Conclusion}

Considering the results, the authors concluded that Listeria spp. is widely distributed in the grocery stores studied, being a potential risk to human health. Additionally, hygienic and sanitary control measures are necessary to minimize the conditions that contribute to the presence of Listeria spp. in retail food stores. The implementation and intensification of inspection and supervision activities by the Health Surveillance Agency is also needed to ensure compliance.

\section{Acknowledgements}

The present study is part of the Master's Degree thesis of Mariana Gomes Ferreira Machado de Siqueira, whose studies were sponsored by the National Council for Scientific and Technological Development (Conselho Nacional de Desenvolvimento Científico e Tecnológico - CNPq). The authors are grateful to 3M and Qiagen ${ }^{\circledR}$ for donating the materials and supplies used in the study.

\section{References}

BARANCELLI, G. V.; SILVA-CRUZ, J. V.; PORTO, E.; OLIVEIRA, C. A. F. Listeria monocytogenes: ocorrência em produtos lácteos e suas aplicações em saúde pública. Arquivos do Instituto Biológico, v. 78, n. 1, p. 155-168, 2011.

BAROCCI, S.; CALZA, L.; BLASI, G.; BRISCOLINI, S.; DE CURTIS, M.; PALOMBO, B.; CUCCO, L.; POSTACCHINI, M.; SABBATINI, M.; GRAZIOSI, T.; NARDI, S.; PEZZOTTI, G. Evaluation of a rapid molecular method for detection of Listeria monocytogenes directly from enrichment broth media. Food Control, v. 19, n. 8, p. 750-756, 2008. http://dx.doi.org/10.1016/j.foodcont.2007.07.013.

BLATTER, S.; GIEZENDANNER, N.; STEPHAN, R.; ZWEIFEL, C. Phenotypic and molecular typing of Listeria monocytogenes isolated from the processing environment and products of a sandwich-producing plant. Food Control, v. 21, n. 11, p. 15191523, 2010. http://dx.doi.org/10.1016/j.foodcont.2010.04.025.

BRASIL. Agência Nacional de Vigilância Sanitária. Ministério da Saúde. Resolução RDC n 12, de 2 de janeiro de 2001. Regulamento Técnico sobre padrões microbiológicos para alimentos. Diário Oficial [da] República Federativa do Brasil, Brasília, DF, 2001.

BRASIL. Agência Nacional de Vigilância Sanitária. Ministério da Saúde. Resolução RDC n² 216, de 15 de setembro de 2004. Dispõe sobre Regulamento Técnico de boas práticas para serviços de alimentação. Diário Oficial [da] República Federativa do Brasil, Brasília, DF, 16 set. 2004.

BRASIL. Ministério da Agricultura, Pecuária e Abastecimento. Instrução Normativa n 9, de 8 de abril de 2009. Procedimentos de controle da Listeria monocytogenes em produtos de origem animal prontos para o consumo. Diário Oficial [da] República Federativa do Brasil, Brasília, DF, 9 abr. 2009.

CASELANI, K.; PRATA, L. F.; BIZARI, P. A.; PEREIRA, G. T.; MARCHI, P. G. F.; PICINATO, M. A. D. C. Occurrence of Listeria spp. and Listeria monocytogenes, at a Slaughterhouse bovine of the state of São Paulo. Bioscience Journal, v. 29, n. 4, p. 956-961, 2013.

CENTERS FOR DISEASES CONTROL AND PREVENTION - CDC. Foodborne outbreak online database (food tool). Atlanta, 2015 Available at: <http://wwwn.cdc.gov/foodborneoutbreaks>. Accessed on: 2 May 2017.

CESAR, A. P. R.; MESQUITA, A. J. M.; PRADO, C. S.; NUNES, I. A.; FILHO, E. S. A. Listeria spp. e Listeria monocytogenes na produção de salsichas tipo hot dog. Ciência Animal Brasileira, v. 12, n. 2, p. 339-352, 2011.

CRUZ, D. C.; MARTINEZ, B. M.; DESTRO, M. T. Listeria monocytogenes: um agente infeccioso ainda pouco conhecido no Brasil. Brazilian Journal of Food and Nutrition, v. 19, n. 2 , p. 195-206, 2008.

EUROPEAN FOOD SAFETY AUTHORITY - EFSA; EUROPEAN CENTRE FOR DISEASE PREVENTION AND CONTROL - ECDC. 
The European Union summary report on trends and sources of zoonoses, zoonotic agents and food-borne outbreaks in 2014. EFSA Journal, v. 13, n. 12, p. 4329, 2016.

FERREIRA, V.; WIEDMANN, M.; TEIXEIRA, P.; STASIEWICZ, M. J. Listeria monocytogenes persistence in food-associated environments: epidemiology, strain characteristics, and implications for public health. Journal of Food Protection, v. 77, n. 1, p. 150-170, 2014. PMid:24406014. http://dx.doi.org/10.4315/0362028X.JFP-13-150.

Ferronatto, A. I.; PEllegrini, D. C. P.; Guerra, P.; CARDOSO, M. R. I. Distribuição de grupos clonais de Listeria monocytogenes em carcaças e no ambiente de matadouros frigoríficos de suínos. Archives of Veterinary Science, v. 17, n. 3, p. 42-49, 2012. http://dx.doi.org/10.5380/avs.v17i3.24940.

GANDHI, M.; CHIKINDAS, M. L. Listeria: a foodborne pathogenic that knows how to survive. International Journal of Food Microbiology, v. 113, n. 1, p. 1-15, 2007. PMid:17010463. http:// dx.doi.org/10.1016/j.ijfoodmicro.2006.07.008.

GELBÍČOVÁ, T.; PANTƯČEK, R.; KARPÍŠKOVÁ, R. Virulence factors and resistance to antimicrobials in Listeria monocytogenes serotype 1/2c isolated from food. Journal of Applied Microbiology, v. 121, n. 2, p. 569-576, 2016. PMid:27238881. http://dx.doi. org/10.1111/jam.13191.

HOELZER, K.; OLIVER, H. F.; KOHL, L. R.; HOLLINGSWORTH, J.; WELLS, M. T.; WIEDMANN, M. Structured expert elicitation about Listeria monocytogenes cross-contamination in the environment of retail deli operations in the United States. Risk Analysis, v. 32, n. 7, p. 1139-1156, 2012. PMid:22053817. http://dx.doi. org/10.1111/j.1539-6924.2011.01729.x.

KAPETANAKOU, A. E.; KARYOTIS, D.; SKANDAMIS, P. N. Control of Listeria monocytogenes by applying ethanol-based antimicrobial edible films on ham slices and microwave-reheated frankfurters. Food Microbiology, v. 54, n. 1, p. 80-90, 2016. http://dx.doi. org/10.1016/j.fm.2015.10.013.

LAKICEVIC, B.; STJEPANOVIC, A.; MILIJASEVIC, M.; TERZICVIDOJEVIC, A.; GOLIC, N.; TOPISIROVIC, L. The presence of Listeria monocytogenes in a chosen food processing establishment in Serbia. Archives of Biological Sciences, v. 62, n. 4, p. 881-887, 2010. http://dx.doi.org/10.2298/ABS1004881L.

LEONG, D.; ALVAREZ-ORDÓÑEZ, A.; JORDAN, K. Monitoring occurrence and persistence of Listeria monocytogenes in foods and food processing environments in the Republic of Ireland. Frontiers in Microbiology, v. 5, n. 436, p. 1-8, 2014. PMid:25191314.

LOTFOLLAHI, L.; CHAHARBALESH, A.; AHANGARZADEH REZAEE, M.; HASANI, A. Prevalence, antimicrobial susceptibility and multiplex PCR-serotyping of Listeria monocytogenes isolated from humans, foods and livestock in Iran. Microbial Pathogenesis, v. 107, n. 1, p. 425-429, 2017. PMid:28445701. http://dx.doi.org/10.1016/j.micpath.2017.04.029.
LUBER, P.; CRERAR, S.; DUFOUR, C.; FARBER, J.; DATTA, A.; TODD, E. C. D. Controlling Listeria monocytogenes in readyto-eat foods: working towards global scientific consensus and harmonization: recommendations for improved prevention and control. Food Control, v. 22, n. 9, p. 1535-1549, 2011. http:// dx.doi.org/10.1016/j.foodcont.2011.01.008.

MAGALHÃES, R.; FERREIRA, V.; BISCOTTINI, G.; BRANDÃO, T. R. S.; ALMEIDA, G.; TEIXEIRA, P. Biofilm formation by persistent and non-persistent Listeria monocytogenes strains on abiotic surfaces. Acta Alimentaria, v. 46, n. 1, p. 43-50, 2017. http:// dx.doi.org/10.1556/066.2017.46.1.6.

MONTEIRO, F. C.; SAMULAR, R. L.; MONTANHINI, M. T. M.; BITTENCOURT, J. V. M. Ocorrência de Listeria monocytogenes em abatedouro-frigorifico de suínos da região dos Campos Gerais - PR. Revista GEINTEC - Gestão, Inovação e Tecnologia, v. 4, n. 5, p. 1583-1593, 2014

MUHTEREM-UYAR, M.; DALMASSO, M.; BOLOCAN, A. S.; HERNANDEZ, M.; KAPETANAKOU, A. E.; KUCHTA, T.; MANIOS, S. G.; MELERO, B.; MINAROVI OVÁ, J.; NICOLAU, A. I.; ROVIRA, J.; SKANDAMIS, P. N.; JORDAN, K.; RODRÍGUEZ-LÁZARO, D.; STESSL, B.; WAGNER, M. Environmental sampling for Listeria monocytogenes control in food processing facilities reveals three contamination scenarios. Food Control, v. 51, n. 1, p. 94-107, 2015. http://dx.doi.org/10.1016/j.foodcont.2014.10.042.

PARISI, A.; LATORRE, L.; FRACCALVIERI, R.; MICCOLUPO, A.; NORMANNO, G.; CARUSO, M.; SANTAGADA, G. Occurrence of Listeria spp. in dairy plants in Southern Italy and molecular subtyping of isolates using AFLP. Food Control, v. 29, n. 1, p. 91-97, 2013. http://dx. doi.org/10.1016/j.foodcont.2012.05.036.

PÉREZ-RODRÍGUEZ, F.; CASTRO, R.; POSADA-IZQUIERDO, G. D.; VALERO, A.; CARRASCO, E.; GARCÍA-GIMENO, R. M.; ZURERA, G. Evolution of hygiene practices and microbiological quality of cooked meat products during slicing and handling at retail. Meat Science, v. 86, n. 2, p. 479-485, 2010. PMid:20573456. http://dx.doi.org/10.1016/j.meatsci.2010.05.038.

RODRIGUES, C. S.; SÁ, C. V. G. C.; MELO, C. B. An overview of Listeria monocytogenes contamination in ready to eat meat, dairy and fishery foods. Ciência Rural, v. 47, n. 2, p. 1-8, 2017. http://dx.doi.org/10.1590/0103-8478cr20160721.

SEYOUM, E. T.; WOLDETSADIK, D. A.; MEKONEN, T. K.; GEZAHEGN, H. A.; GEBREYES, W. A. Prevalence of Listeria monocytogenes in raw bovine milk and milk products from central highlands of Ethiopia. Journal of Infection in Developing Countries, v. 9, n. 11, p. 1204-1209, 2015. PMid:26623629. http://dx.doi. org/10.3855/jidc. 6211 .

SILVA, D. A.; CAMARGO, A. C.; TODOROV, S. D.; NERO, L. A. Listeria spp. contamination in a butcher shop environment and Listeria monocytogenes adhesion ability and sensitivity to foodcontact surface sanitizers. Journal of Food Safety, v. 37, n. 2, p. e12313, 2017. http://dx.doi.org/10.1111/jfs.12313. 
Detection of Listeria spp. in food handling areas of retail food stores in the state of Pernambuco, Brazil Siqueira, M. G. F. M. et al.

SILVA, N.; JUNQUEIRA, V. C. A.; SILVEIRA, N. F. A.; TANIWAKI, M. H.; SANTOS, R. F. S.; GOMES, R. A. R. Manual de métodos de análises microbiológica de alimentos e água. São Paulo: Varela, 2010. 109 p.

SÖDERQVIST, K.; LAMBERTZ, S. T.; VÅGSHOLM, I.; BOQVIST, $S$. Foodborne bacterial pathogens in retail prepacked readyto-eat mixed ingredient salads. Journal of Food Protection, v. 79, n. 6, p. 978-985, 2016. PMid:27296602. http://dx.doi. org/10.4315/0362-028X.JFP-15-515.

SU, X.; ZHANG, J.; SHI, W.; YANG, X.; LI, Y.; PAN, H.; KUANG, D.; XUEBIN, X.; XIANMING, S.; MENG, J. Molecular characterization and antimicrobial susceptibility of Listeria monocytogenes isolated from foods and humans. Food Control, v. 70, p. 96-102, 2016. http://dx.doi.org/10.1016/j.foodcont.2016.04.020.

TEIXEIRA, J. S.; MAIER, M. B.; MILLER, P.; GANZLE, M. G.; MCMULLEN, L. M. The effect of growth temperature, process temperature, and sodium chloride on the high-pressure inactivation of Listeria monocytogenes on ham. European Food Research and Technology, v. 242, n. 12, p. 2021-2029, 2016. http://dx. doi. org/10.1007/s00217-016-2700-6.

WORLD HEALTH ORGANIZATION - WHO; FOOD AND AGRICULTURE ORGANIZATION OF THE UNITED NATIONS FAO; CODEX ALIMENTARIUS COMMISSION - CAC. Guidelines on the application of general principles of food hygiene to the control of Listeria monocytogenes in food: CAC/GL 61 . Rome: WHO/FAO, 2009. (Codex Alimentarius - International Food Standards).

YAMAGUCHI, U. M.; ZANQUETA, E. B.; MOARAIS, J. F.; FRAUSTO, H. S. E. G.; SILVÉRIO, K. I. Qualidade microbiológica de alimentos e de ambientes de trabalho: pesquisa de Salmonella e Listeria. Revista em Agronegócio e Meio Ambiente, v. 6, n. 3, p. 417-434, 2013. 